\title{
Effect of firing temperature on sintering of porcelain stoneware tiles
}

\author{
J. Martín-Márquez, J. Ma. Rincón and M. Romero* \\ Group of Glassy and Ceramic Materials, Department of Building Construction Systems, \\ Institute of Science Construction "Eduardo Torroja" (CSIC), C/ Serrano Galvache 4, \\ 28033, Madrid, Spain
}

* Corresponding author. Tel.: +34 913020440; fax: +34 913020700.

E-mail address: mromero@ietcc.csic.es (M. Romero).

\begin{abstract}
Porcelain stoneware tile is a non-equilibrium porcelain material produced by a fast firing process of kaolinitic clay, quartz and feldspar mixtures. This building material, generally used in pavements and also as wall covering and ventilated façades, is endowed with high technological properties such as low water absorption, high bending strength and abrasion resistance and excellent chemical and frost resistance. These properties cause that porcelain stoneware tile was actually the material with the highest increase in production and sales over all other ceramic building material. Nevertheless, there is a scarcity of high quality research focused on the effect of mullite growth on technological properties of porcelain stoneware tile and on the effect of different fluxing agents on both mullite growth and evolution of physical and technological properties during firing. In this paper, the behaviour of a potassic porcelain stoneware body during the firing process is investigated. A porcelain stoneware composition was prepared by mixing 50\% kaolinitic clay, $40 \%$ feldspar and 10\% quartz. The samples were sintered following a fast firing process. The sintering behaviour of the fired samples was evaluated by linear shrinkage, water absorption and porosity measurements. Both green powder and fired samples were characterized by means of differential thermal analysis (DTA), X-ray diffraction (XRD), scanning electron microscopy (SEM), dilatometry and bending strength measurements.
\end{abstract}

Keywords: A. Sintering; D. Porcelain stoneware; C. Technological properties; E. Functional applications

\section{Introduction}

Porcelain is a vitrified product of mixtures of clay, quartz and feldspar. Porcelain microstructures are grain and bond type with large particles of filler (usually quartz) held together by a finer matrix, which is almost fully dense, composed by mullite crystals and a glassy phase $[1,2]$. Because of the complex interplay between raw materials, processing routes and approaches, and the kinetics of the firing process, porcelains represent some of the most complicate ceramic systems [3].

Porcelain stoneware tile is a derived porcelain building material characterized by a very compact microstructure and high technical characteristics [4]. The main difference between porcelain and porcelain stoneware lies on their firing schedule. Thus, porcelain 
is fired following a long time (several hours) process in order to promote a high mullite formation whereas porcelain stoneware tile is fabricated by a faster firing cycle (60-90 min cold-to-cold in porcelain stoneware compared to $24 \mathrm{~h}$ or more in porcelain), in which the tiles are inside the furnace no longer than 60-90 min. The different firing process leads to big differences in the percentage of crystalline phases in the end products and whereas mullite and glass constitute the major phases of porcelain, which also contains some quartz, cristobalite and tridymite, in porcelain stoneware tile quartz is more abundant than mullite. Most of the reactions occurring during firing are kinetically governed processes [3] that do not reach thermodynamic equilibrium in porcelain stoneware production, since the industrial cycles are shorter than 1 hour. Thus, we can say that, because of fast firing process, porcelain stoneware is a nonequilibrium material.

The high technological properties of porcelain stoneware, especially as regards water absorption, chemical and frost resistance, bending strength and abrasion resistance, cause that porcelain stoneware tile was actually the material with the highest increase in production and sales over all other ceramic building material. Typical composition of commercial porcelain stoneware tile is $40-50 \mathrm{wt} . \%$ kaolin clays, $35-45 \mathrm{wt} . \%$ feldspars; $10-15$ wt.\% quartz [5].

However, the commercial interest in porcelain stoneware tile is accompanied by a scarcity of high quality research and although it is possible to find in the literature several papers on this material, they are mainly focused on processing [6-11], feasibility of different raw materials to produce porcelain stoneware tiles [12-15] and general information [16-20]. The relationship of microstructure on the technological properties of fired products has been less well studied, being the research in this field focused on glass phase formation and porosity evolution [4, 21-26]. It is important to point out that the effect of mullite growth on technological properties of porcelain stoneware tile has not been previously investigated, leaving significant opportunities for research in this field.

The present work is part of a more extensive investigation with two main objectives. The first is to establish the effect of mullite crystals growth (percentage, shape and size) on physical and technological properties of porcelain stoneware tiles and secondly, to study the effect of feldspar substitution by different fluxing agents on both mullite phase growth and evolution of physical and technological properties during firing. For this purpose, it is very important to have a previous knowledge of the behaviour of a porcelain stoneware body during the firing process, being this the objective of the present paper. With this aim, a porcelain stoneware composition has been formulated with following criteria:

- It must be a conventional composition, similar to that used in traditional ceramic covering and pavement factories, but without additive supplement, such as synthetic inorganic pigments synthetic inorganic pigments or pressing additives as binders or plasticizers, and,

- It must lead to the maximum formation of mullite phase. For this reason, the composition has been prepared with the maximum percentage of kaolinitic clay and the minimum quartz content. 


\section{Experimental Procedure}

Raw materials used in the present investigation were kaolinitic clay and feldspar (provided by Compañía Europea de Arcillas, S.A. and designed as AR-2097-G and FC100 respectively), and quartz sand (facilitated by IETcc, CSIC). Chemical composition, as determined by inductively coupled plasma optical emission spectroscopy (ICP-OES), and mineralogical composition determined by X-ray diffraction (XRD) are shown in Table I. All the above materials were crushed, ground and finally powdered to $<160 \mu \mathrm{m}$ prior to further use.

Table I. Chemical and mineralogical analyses of raw materials used in this work

\begin{tabular}{|c|c|c|c|}
\hline & \multicolumn{3}{|c|}{ Content (wt\%) } \\
\hline & Kaolinitic clay & Feldspar & Quartz sand \\
\hline $\mathrm{SiO}_{2}$ & 58.10 & 69.86 & 98.88 \\
\hline $\mathbf{A l}_{2} \mathbf{O}_{3}$ & 27.60 & 16.45 & 1.08 \\
\hline $\mathrm{Fe}_{2} \mathrm{O}_{3}$ & 1.58 & 0.06 & 0.31 \\
\hline $\mathrm{CaO}$ & 0.26 & 0.54 & 0.08 \\
\hline MgO & 0.40 & 0.06 & $<0.10$ \\
\hline $\mathrm{Na}_{2} \mathrm{O}$ & ----- & 2.28 & $<0.07$ \\
\hline $\mathbf{K}_{2} \mathbf{O}$ & 1.62 & 10.20 & $<0.10$ \\
\hline $\mathrm{TiO}_{2}$ & 0.65 & 0.05 & 0.57 \\
\hline MnO & 0.01 & ----- & 0.01 \\
\hline $\mathbf{P}_{2} \mathbf{O}_{5}$ & 0.16 & ----- & $<0.10$ \\
\hline LOI & 9.40 & 0.50 & 0.28 \\
\hline $\begin{array}{l}\text { Mineralogical } \\
\text { composition }\end{array}$ & $\begin{array}{l}70.6 \% \text { kaolinite } \\
12.7 \% \text { illite } \\
10.6 \% \text { quartz } \\
6.1 \% \text { others }\end{array}$ & $\begin{array}{l}65 \% \text { microcline } \\
20 \% \text { albite } \\
13 \% \text { quartz } \\
2 \% \text { others }\end{array}$ & $\begin{array}{l}\text { Mainly quartz } \\
\text { microcline as minor phase }\end{array}$ \\
\hline
\end{tabular}

A potassic porcelain stoneware composition was prepared by mixing 50\% kaolinitic clay, $40 \%$ feldspar and $10 \%$ quartz. Batches (300 g each) were prepared by milling the constituents with distilled water (1:1) for $30 \mathrm{~min}$, in a planetary ball mill (TURBULA) and using alumina balls as grinding media. The resultant slurry was oven-dried overnight at $110^{\circ} \mathrm{C}$, powdered in a porcelain mortar and pestle, and sieved to pass -100 mesh $(150 \mu \mathrm{m})$.

The resulting powder was moistened by spraying with distilled water (6 wt \%) and uniaxially pressed at $40 \mathrm{MPa}$ in a steel die. Discs of $20 \mathrm{~mm}$ diameter and $5 \mathrm{~mm}$ height were shaped from $3 \mathrm{~g}$ of powder. Moreover, square tiles (30 g each) of 50x50x8mm were prepared for bending strength measurements. After drying in an oven at $110^{\circ} \mathrm{C}$ the compacts were placed on alumina rollers in an electric furnace and fired between $1200^{\circ}$ 
and $1300^{\circ} \mathrm{C}$ following a fast firing process. The samples were heated for $\sim 30 \mathrm{~min}$ to the required temperature, soaked for $15 \mathrm{~min}$ and then cooled in the furnace at $50^{\circ} \mathrm{C} / \mathrm{min}$ to room temperature.

Differential thermal analysis (DTA) was performed on the porcelain stoneware powder, using a Setaram (Labsys) DTA unit in air atmosphere. The test was carried out at a heating rate of $50^{\circ} \mathrm{C} / \mathrm{min}$, in platinum crucibles and calcined alumina as reference.

The sintering behaviour of the fired samples was evaluated by using the vitrification curves, which present the variation in properties of a ceramic as a function of firing temperature for otherwise identical firing schedules in terms of heating rates, cooling rates and soak times at peak temperatures [27, 28]. Vitrification curves allow establishing the optimum firing temperature and the firing range at which the open porosity reaches a minimum, which usually corresponds to higher values of mechanical strength. Linear shrinkage and water absorption, which is directly related with open porosity, are properties easy to measure and hence, are usually used to represent the vitrification curves.

The linear shrinkage, LS (\%), of fired samples has been determined by means of the following equation:

$$
\mathrm{LS}=\frac{\mathrm{L}_{\mathrm{s}}-\mathrm{L}_{\mathrm{c}}}{\mathrm{L}_{\mathrm{s}}} \times 100
$$

being $\mathrm{L}_{\mathrm{s}}$ and $\mathrm{L}_{\mathrm{c}}$ the diameter $(\mathrm{mm})$ of the green and fired specimens respectively. The linear shrinkage values obtained of six specimens were averaged for each firing temperature.

The water absorption, bulk density and apparent porosity were measured according to ASTM C373-88, which involves drying the test specimens to constant mass (D), boiling in distilled water for $5 \mathrm{~h}$ and soak for an additional $24 \mathrm{~h}$ at ambient temperature. After impregnation, the mass (S) of each specimen while suspended in water and their saturated mass $(\mathrm{M})$ is determined. The test was carried out on four representative specimens.

Water absorption, WA (\%), expresses the relationship of the mass of water absorbed to the mass of the dry specimen as follows:

$$
\mathrm{WA}=\frac{\mathrm{M}-\mathrm{D}}{\mathrm{D}} \times 100
$$

The bulk density, $\mathrm{B}\left(\mathrm{g} / \mathrm{cm}^{3}\right)$, is calculated as follows:

$\mathrm{B}=\frac{\mathrm{D}}{\mathrm{V}}$

where $\mathrm{V}\left(\mathrm{cm}^{3}\right)$ is the exterior volume $(\mathrm{V}=\mathrm{M}-\mathrm{S})$. 
The open porosity, $\varepsilon_{\mathrm{o}}(\%)$, expresses the relationship of the volume of open pores to the exterior volume of the specimen and is calculated as follows:

$$
\varepsilon_{\mathrm{o}}=\frac{\mathrm{M}-\mathrm{D}}{\mathrm{V}} \times 100
$$

The total porosity of the sample, $\varepsilon_{\mathrm{T}}(\%)$ is determined by the following equation:

$$
\varepsilon_{\mathrm{T}}=\left(1-\frac{\mathrm{B}}{\mathrm{AD}}\right) \times 100
$$

where $\mathrm{AD}\left(\mathrm{g} / \mathrm{cm}^{3}\right)$ is the absolute density of the sample, which was previously measured according to ASTM C329-88. The test method involves crush, ground and sieve the sample to pass -80 mesh $(177 \mu \mathrm{m})$. The measurements were carried out on 8 $10 \mathrm{~g}$ of powder sample by using a pycnometer (50 ml capacity) consisting of a suitable bottle with a capillary tube stopper. All determinations have been made in duplicate.

The close porosity, $\varepsilon_{\mathrm{c}}(\%)$, is then calculated as follows:

$\varepsilon_{\mathrm{c}}=\varepsilon_{\mathrm{T}}-\varepsilon_{\mathrm{o}}$

For analysis of porosity evolution during firing, the microstructure of fired specimens were examined by Scanning Electron Microscopy (SEM) in a Philips XPERT microscope using an accelerate voltage of $20 \mathrm{kV}$. SEM samples were polished to $1 \mu \mathrm{m}$ finish with diamond pastes after initial grinding with $\mathrm{SiC}$ powder. For SEM observation the specimens were Au-Pd coated in a Balzers SCD 050 sputter.

The coefficients of linear thermal expansion of the green body and specimens fired at $1200^{\circ}$ and $1280^{\circ} \mathrm{C}$ were determined in a TMA CX03R equipment between room temperature and $750^{\circ} \mathrm{C}$ at a heating rate of $10^{\circ} \mathrm{C} / \mathrm{min}$.

Samples fired at the selected optimum temperature range were examined by SEM, Xray diffractometry (XRD) and subjected to the determination of mechanical properties. For analysis of phase assemblages and morphology by SEM, the fresh fracture surfaces were etched for 4 min in 15\% HF solution, washed ultrasonically with distilled water and ethylic alcohol, dried and subsequently Au-Pd coated. The crystalline phases were identified by XRD in a Philips X'PERT MPD diffractometer. For XRD powder sample (sieved $<60 \mu \mathrm{m}$ ) were scanned in the range $2 \theta=5-75^{\circ}$ at a scanning speed of $0.5^{\circ} \mathrm{min}^{-1}$, using $\mathrm{Cu} \mathrm{K} \mathrm{K}_{\alpha}$ radiation at $50 \mathrm{kV}$ and $30 \mathrm{~mA}$. JCPDS Cards 46-1045 (quartz), and 15-776 (mullite) were used to identify crystals phases.

Finally, bending strength was measured according to UNE-EN 843-1 in an electronic universal tester (Servosis) on 10 test pieces of $50 \times 10 \times 8 \mathrm{~mm}$ by a three-point loading test with a span of $36 \mathrm{~mm}$ and crosshead speed of $3 \mathrm{~mm} / \mathrm{min}$. Vickers microhardness and fracture toughness measurements were performed using the indentation technique with a load of $1000 \mathrm{~g}$ for a dwell time of $15 \mathrm{~s}$ in a Matsuzawa Hardness tester. Samples were ground on silicon carbide paper, and then polished using 6,3 and $1 \mu \mathrm{m}$ diamond pastes 
prior to measurements. For each case a mean of 10 measurements was taken. The cracks were measured immediately after indentation, thereby minimising any subcritical crack growth caused by residual stresses. Crack measurements were only made on indents that were well defined without chipping and for which the cracks did not terminate at pores. Young's modulus was measured by the resonance frequency method (Grindosonic analyser).

\section{Results and Discussion}

A homogeneous powder of the porcelain stoneware composition is obtained as result of mixing, milling and sieved steps. Figure 1 depicts the DTA/TG curve recorded from the powder of the porcelain stoneware composition. A broad endothermic band centred at $\sim 550^{\circ} \mathrm{C}$ is due to both clay dehydroxylation reaction and $\alpha \rightarrow \beta$ quartz transformation. The mass loss associated to this endothermic is $4.68 \%$, which is very close to the theoretical mass loss of $4.9 \%$ corresponding to the kaolinitic clay content in the composition. An exothermic peak at $\sim 1000^{\circ} \mathrm{C}$ is attributable to mullite crystallization. Finally, an endothermic descent at higher temperatures indicates the formation of a liquid phase mainly derived from the feldspar component. The amorphous silica liberated during the metakaolin decomposition or the impurities contained in the raw materials could also contribute to liquid phase formation.

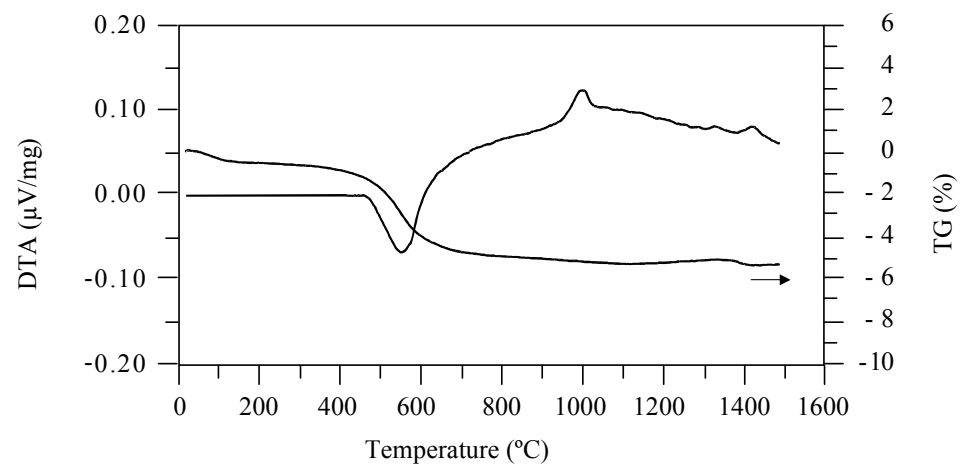

Figure 1. DTA/TG curves recorded on the powder of the porcelain stoneware composition.

The body shows a good sintering behaviour. The fired samples are homogeneous and free of defects such as holes, bubbles or cracks. Figure 2 shows the open, close and total porosity as function of firing temperature at the $1200^{\circ}-1300^{\circ} \mathrm{C}$ range range. Upon firing, these properties show the typical trend of a ceramic body sintered by a viscous liquid phase mechanism [29]. In fact, it is apparent that open porosity decreases with increasing firing temperature due to the formation of a glassy phase that is mainly originated from the feldspar. Increasing temperatures cause both an increase in liquid phase amount and a decrease in liquid phase viscosity. Under the surface energy forces created by the fine pores contained in the ceramic body, the liquid phase tends to approach the particles and, therefore, open porosity decreases [27]. Simultaneously, closed porosity increases in the whole firing temperature range, being this increasing considerable above $1280^{\circ} \mathrm{C}$ because of the so-called body bloating due to the pressure of the gas inside the closed pores, which tends to expand the pores [25]. The combination 
of both open and closed porosity gives rise to the total porosity decrease in the first steps of sintering, reaching a minimum value at $1280^{\circ} \mathrm{C}$ and then increasing. This behaviour is similar to that showed by almost all porcelain bodies.

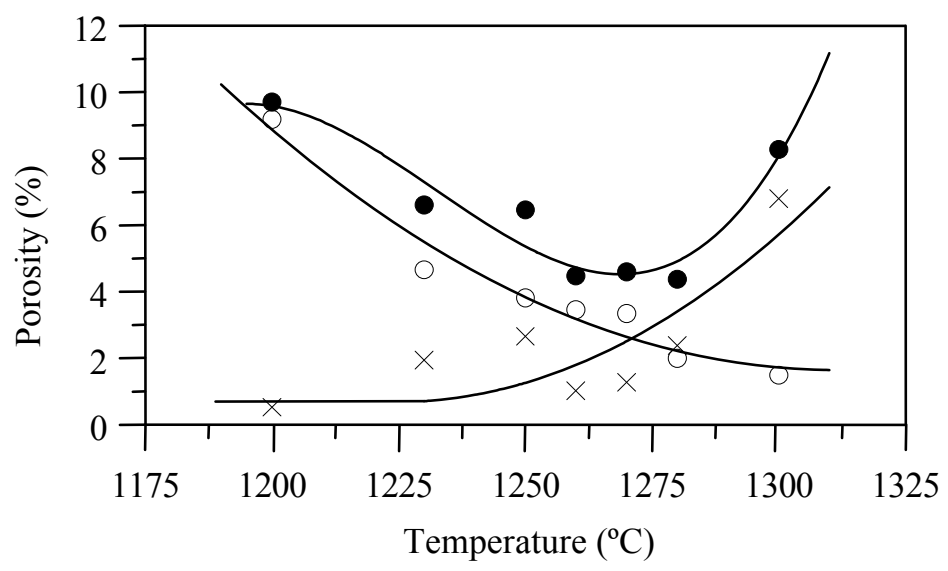

Figure 2. Open (o), close $(\mathrm{X})$ and total $(\bullet)$ porosity of the porcelain stoneware samples as function of firing temperature.

Figure 3 shows SEM observations on polished surfaces of the porcelain stoneware fired at different temperatures at the $1200^{\circ}-1300^{\circ} \mathrm{C}$ range. It is noted the existence of both open and close porosity in the fired samples.

Open porosity consists of fine, interconnected pores with irregular shape. On the other hand, closed porosity is due to larger, isolated and spherical pores. The size of closed pores increases with firing temperature, from an average diameter of $\sim 5 \mu \mathrm{m}$ at $1200^{\circ} \mathrm{C}$ to $100 \mu \mathrm{m}$ at $1300^{\circ} \mathrm{C}$.

Figure 3 shows that a dense matrix is observed at $1250^{\circ} \mathrm{C}$, especially above $1260^{\circ} \mathrm{C}$, indicating that below $1260^{\circ} \mathrm{C}$ the sintering temperature was not high enough to yield dense ceramic materials.

It is necessary to point out that the sintering process in porcelain stoneware samples does not exactly proceed by the foreseen way of a liquid phase mechanism. Kingery [29] establishes two different steps during sintering. The first shows a decreasing in open porosity, which is coincident with an increasing in the sample shrinkage. The sintering process is not finished when open porosity completely disappears. In the second steps, the ceramic body could be represented as a conjunction of small and closed pores. The surface energy forces inside each pore give rise to a negative pressure, which tends to densify the ceramic body. However, Figures 2-3 show that in the porcelain stoneware samples, the closed porosity starts to increase before open porosity totally disappears. This behaviour is due to both mullite crystallization and quartz dissolution in the liquid phase, which originate an increasing in the viscosity of liquid phase and hence, the removal of open porosity is delayed. 


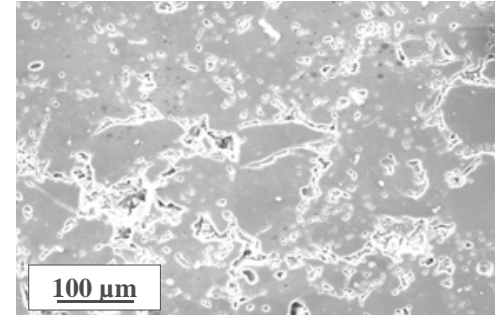

$1200^{\circ} \mathrm{C}$

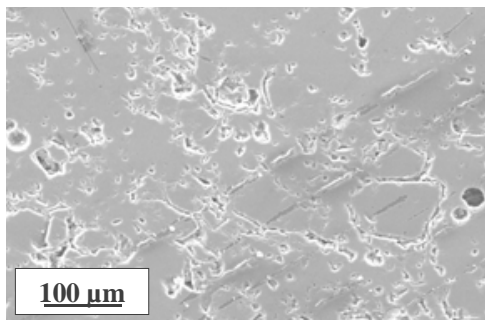

$1250^{\circ} \mathrm{C}$

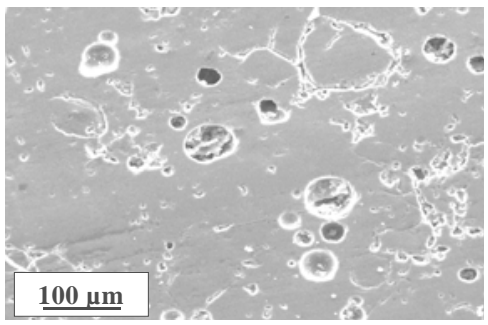

$1275^{\circ} \mathrm{C}$

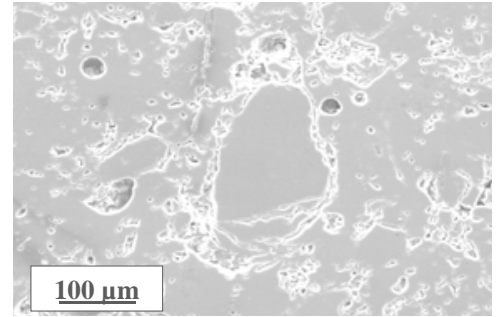

$1230^{\circ} \mathrm{C}$

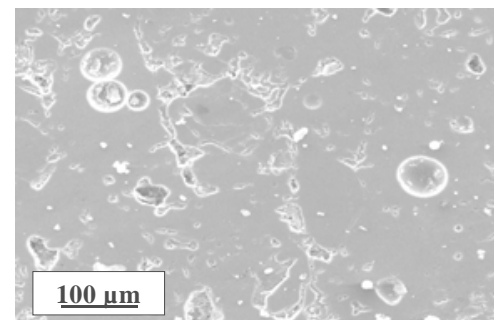

$1260^{\circ} \mathrm{C}$

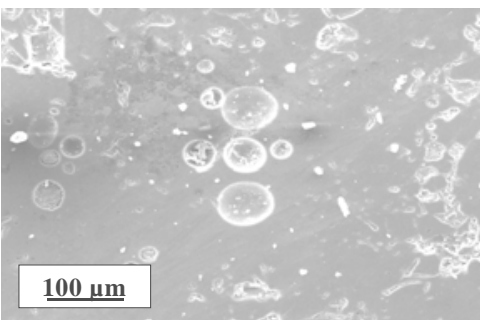

$1280^{\circ} \mathrm{C}$

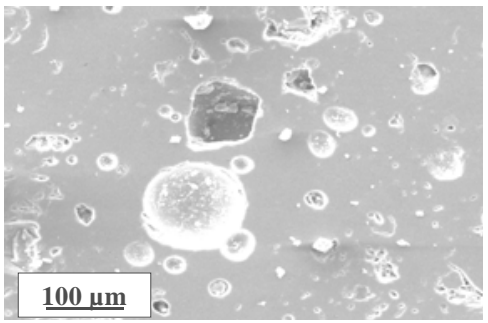

$1300^{\circ} \mathrm{C}$

Figure 3. SEM observations on polished surfaces of the porcelain stoneware fired at different temperatures in the $1200^{\circ}-1300^{\circ} \mathrm{C}$ range.

The porosity of the fired sample is associated to other physical properties such as linear shrinkage and water absorption. Figure 4 shows the former properties as function of firing temperature at the $1200^{\circ}-1300^{\circ} \mathrm{C}$ range. Total porosity depicts a similar trend that linear shrinkage, which initially increases, reaches a maximum value, and above $1280^{\circ} \mathrm{C}$ decreases due to close porosity increasing. Finally, since water absorption is directly related to open porosity, its value decreases in the overall temperature range.

To discuss the degree of densification, bulk density rather than absolute density must be compared, because the content of crystalline phases affects absolute density. It has been observed that bulk density has a similar behaviour than linear shrinkage, an initial increase is followed by an abrupt decrease in the relative density because the so-called bloating [30]. 
The optimum vitrification range is achieved when open porosity reaches a minimum value, tending to be nearly zero, and simultaneously linear shrinkage is maximum. Firing above vitrification range results in a drastic fall of the physical properties due to forced expulsion of the entrapped gases, resulting in blisters and bloating. From Figures 3-5 it can be established that in this porcelain stoneware paste the optimum firing temperature is in the $1260^{\circ}-1280^{\circ} \mathrm{C}$ range.

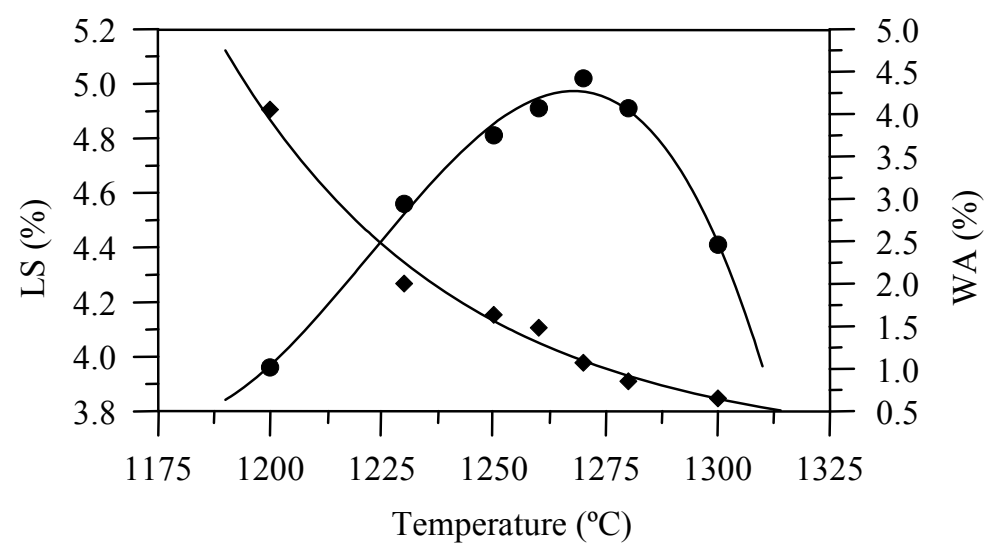

Figure 4. Linear shrinkage (LS) and water absorption (WA) in the porcelain stoneware samples as function of firing temperature $(\bullet \mathrm{LS} ; \bullet \mathrm{WA})$.

Figure 5 shows the X-ray diffractograms of the porcelain stoneware body fired in the $1260^{\circ}-1280^{\circ} \mathrm{C}$ interval. Quartz is the only mineral phase existing in the green body and detected in the fired products. All the other mineral phases existing in the raw materials (Table I) have disappeared, being replaced by mullite and glassy phase.

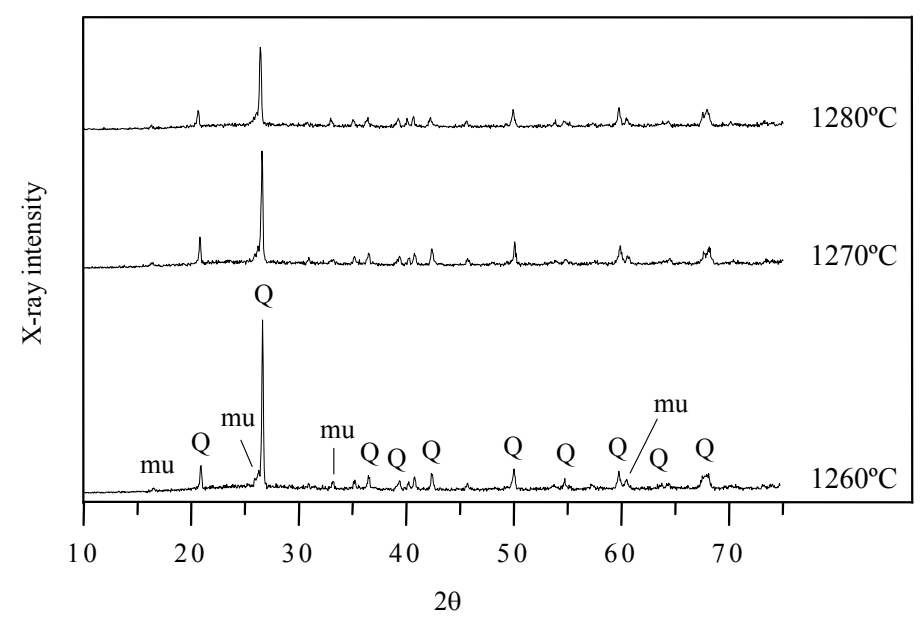

Figure 5. X-ray diffractograms of the porcelain stoneware body fired in the $1260^{\circ}$ $1280^{\circ} \mathrm{C}$ interval.

Figure 6 shows SEM observations on the fracture of the porcelain stoneware body fired at $1260^{\circ} \mathrm{C}$. It is observed the typical grain and bond microstructure of porcelain consisting of quartz grains held together by a finer matrix or bond that is almost fully dense [1]. Some quartz grains are cracked due to both the $\alpha \rightarrow \beta$ quartz transformation at $\sim 573^{\circ} \mathrm{C}$ during the firing-cooling process and the release of microstresses within quartz 
grains and surrounding glassy phases from their large thermal expansion coefficient difference [31]. The matrix is composed by primary mullite, originated from pure clay agglomerate relicts and consisting in aggregates of small scaly crystals and secondary mullite composed of elongated needle-shape crystals derived from feldspar-clay relicts $[2,32]$.

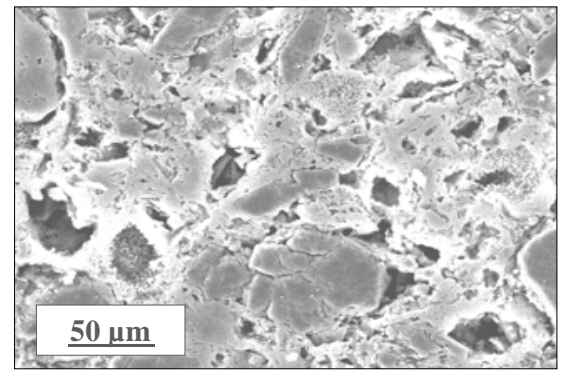

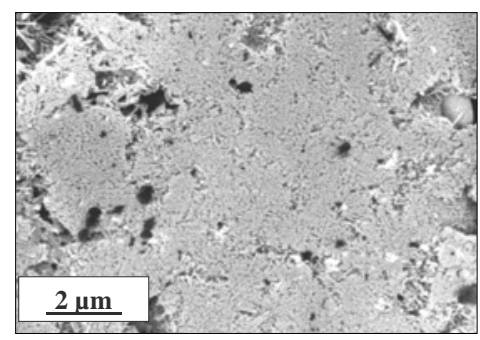

primary mullite

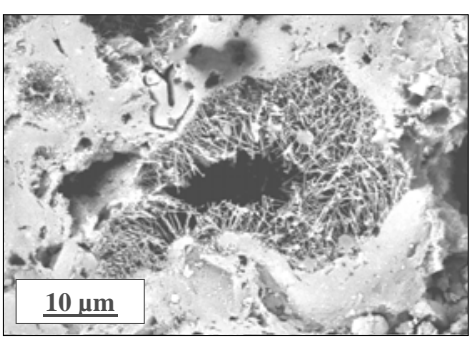

secondary mullite

Figure 6. SEM observations on the fracture of the porcelain stoneware body fired at $1260^{\circ} \mathrm{C}$.

As regard mechanical properties, the average bending strength of samples fired in the $1260^{\circ}-1280^{\circ} \mathrm{C}$ range is $34 \pm 2 \mathrm{MPa}$, which is in the order of the $>35 \mathrm{MPa}$ prescribed in the standard EN14411 (Annex G) for these ceramic materials. Table II collects the average values of microhardness $\left(\mathrm{H}_{\mathrm{v}}\right)$, Young's modulus $(\mathrm{E})$ and fracture toughness $\left(\mathrm{K}_{\mathrm{IC}}\right)$ of the porcelain stoneware body fired in the $1260^{\circ}-1280^{\circ} \mathrm{C}$. These values are comparable to that showed by commercial porcelain stoneware tiles [4], which are also showed in Table II.

Table II. Average values of microhardness $\left(\mathrm{H}_{\mathrm{v}}\right)$, Young's modulus $(\mathrm{E})$ and fracture toughness $\left(\mathrm{K}_{\mathrm{IC}}\right)$ of the porcelain stoneware body fired in the $1260^{\circ}-1280^{\circ} \mathrm{C}$.

\begin{tabular}{|l|c|c|c|}
\cline { 2 - 4 } \multicolumn{1}{c|}{} & $\mathbf{H}_{\mathbf{v}}(\mathbf{G P a})$ & $\mathbf{E}(\mathbf{G P a})$ & $\mathbf{K}_{\mathbf{I C}}\left(\mathbf{M P a} \cdot \mathbf{m}^{\mathbf{1} / \mathbf{2}}\right)$ \\
\hline Value measured & $5.4 \pm 0.6$ & $72 \pm 0.5$ & $1.3 \pm 0.2$ \\
\hline Values showed by commercial tiles [4] & $5.5 \pm 0.4$ & $70 \pm 1$ & $1.9 \pm 0.8$ \\
\hline
\end{tabular}

\section{Conclusions}

A mixture of $50 \%$ kaolinitic clay, $40 \%$ feldspar and 10\% quartz was selected as representative composition of commercial porcelain stoneware tiles produced by a fastfiring process. All bodies show a good sintering behaviour after firing in the $1200^{\circ}$ - 
$1300^{\circ} \mathrm{C}$ range. The fired samples are homogeneous and free of defects such as holes, bubbles or cracks. Linear shrinkage, water absorption and porosity determinations show that the sintering process in porcelain stoneware samples does not exactly proceed by a viscous liquid phase mechanism. Close porosity starts to increase before open porosity totally disappears. This behaviour is due to both mullite crystallization and quartz dissolution in the liquid phase, which originate an increasing in the viscosity of liquid phase and hence, the removal of open porosity is delayed. The optimum firing temperature is achieved in the $1260^{\circ}-1280^{\circ} \mathrm{C}$ range, when open porosity reaches a minimum value and simultaneously linear shrinkage is maximum. Firing above vitrification range results in a drastic fall of the physical properties due to forced expulsion of the entrapped gases, resulting in blisters and bloating.

X-ray diffractograms of samples fired in the optimum firing temperature interval show that the samples are composed by quartz, mullite and glassy phase. SEM observations on the fracture of fired samples present the typical grain and bond microstructure of porcelain consisting of quartz grains held together by a dense matrix composed by primary and secondary mullite crystals.

The average bending strength of samples fired in the $1260^{\circ}-1280^{\circ} \mathrm{C}$ range is $34 \pm 2 \mathrm{MPa}$, which is fulfilling with a value $>35 \mathrm{MPa}$ prescribed for these ceramic materials. The values of microhardness (5.4 GPa), Young's modulus (72 GPa) and linear expansion coefficient $\left(67 \times 10^{-7}{ }^{\circ} \mathrm{C}^{-1}\right)$ are comparable to those showed by commercial porcelain stoneware tiles.

\section{Acknowledgements}

This research was supported by the Spanish Science and Technology Ministry (Projects MAT2000-1422 and MAT2003-2915). The authors are gratefully acknowledged to Compañía Europea de Arcillas, S.A. for providing raw materials. The authors thanks to Prof. J. Malek from the University of Pardubiçe, (Czech Republic), for facilitate the determination of thermal expansion curves Thanks are also due to Mr. A. Luna and Mr. C. Rivera from University of Castilla-La Mancha (Spain) for their experimental assistance.

\section{References}

1. W.E. Lee, W.M. Rainforth, Ceramic Microstructures, Chapman and Hall, UK, 1995.

2. Y. Iqbal, W.E. Lee, Fired porcelain microstructure revisited, Journal of the American Ceramic Society 82 (12) (1999) 3584-90.

3. W.M. Carty, U. Senapati, Porcelain - raw materials, processing, phase evolution, and mechanical behaviour, Journal of the American Ceramic Society 81 (1) (1998) 320.

4. L. Barbieri, L. Bonfatti, A.M. Ferrari, C. Leonelli, T. Manfredini, D. Settembre Blundo, Relationship between microstructure and mechanical properties in fully vitrified stoneware, in P. Vincenzini (Ed.), Ceramics: Charting the Future, Vol. 3A, Techna Srl, Modena, 1995, pp. 99-105. 
5. F. Andreola, L. Barbieri, A. Corradi, I. Lancellotti, T. Manfredini, Utilisation of municipal incinerator grate slag for manufacturing porcelainized stoneware tiles manufacturing, Journal of the European Ceramic Society 22 (9-10) (2002) 1457-1462.

6. C. Viola, B. Tabakovic, Porcellanato o porcellana? Evolutione ed ottimizzazioni nella tecnología cerámica del pavimento ad alta sinterizzazione, Cerámica Informazione (336) (1994) 171-175.

7. E. Sánchez, F. Ginés, J. García, C. Feliú, Evaluating lamination in porcelain tile. Part II. Pressing cycle and powder characteristics, American Ceramic Society Bulletin 77 (4) (1998) 81-85.

8. A. Cappi, J. Previde Massara, V. Venturi, Ventajas de la micronización en el empleo de feldespatos en las mezclas de porcelánico, Cerámica Información, 27 (271) (2001) 53-62.

9. A. Bresciani, G.P. Graziani, C. Ricci, New grès porcellanato tile manufacturing technology: Pre-pressing, dry decoration, and green cutting, Interceram 51 (6) (2002) 380-386.

10. E. Sánchez, Technical considerations on porcelain tile products and their manufacturing process, Part I., Interceram 52 (1) (2003) 6-16.

11. E. Sánchez, Technical considerations on porcelain tile products and their manufacturing process, Part II, Interceram 52 (3) (2003) 132-138.

12. J. Peñalver, M.D. Llanes, E. Cerisuelo, I. Nebot-Díaz, M. Irún, J.B. Carda, Cerámica Información 26 (267) (2000) 95-115.

13. G. Bedoni, C. Carbonchi, P. Danasino, Comportamiento durante la cocción de las pastas de gres porcelánico frente a la relación $\mathrm{Na} / \mathrm{K}$, Cerámica Información 27 (272) (2001) 61-66.

14. L. Sánchez-Muñóz, I. Nebot-Díaz, J.B. Carda, F. Tuduri, A. Gracia, E. Cerisuelo, Obtención de soportes cerámicos de baja porosidad a partir de materias primas nacionales, Cerámica Información 27 (272) (2001) 48-54.

15. F.M. Motta, J.M. Coelho, M.C. Junior, A. Zanardo, L.C. Tanno, Raw materials for porcelainized stoneware tiles ceramic bodies in Brazil, Tile \& Brick International 18 (6) (2002) 358-362.

16. F. Corma, Tendencias del gres porcelánico, Técnica Cerámica (270) (1999) 186189.

17. G. Biffi, El mercado del gres porcelánico en Europa: Desarrollos y perspectivas, Cerámica Información 25 (251) (1999) 69-76.

18. P. Corma, Gres porcelánico en España. Previsiones, Cerámica Información 26 (268) (2000) 55-56.

19. P. Burzacchini, Porcelain tile, its history and development, Ceramic World Review (37) (2000) 96-103.

20. G. Savorani, G. Biffi, Por qué producir gres porcelánico: Factores económicos y de mercado, Cerámica Información 27 (276) (2001) 53-60.

21. M. Dondi, G. Ercolani, C. Melandri, C. Mingazzini, M. Marsigli, The chemical composition of porcelain stoneware tiles and its influence on microstructural and mechanical properties, Interceram 48 (2) (1999) 75-83. 
22. T. Manfredini, G.C. Pellacani, M. Romagnoli, L. Pennisi, Porcelainized stoneware tiles, American Ceramic Society Bulletin 74 (5) (1995) 76-79.

23. E. Sánchez, M.J. Orts, J. García-Tena, V. Cantavella, Porcelain tile composition effect on phase formation and end products, American ceramic Society Bulletin 80 (6) (2001) 43-49.

24. M. Dondi, B. Fabbri, T. Manfredini, G.C. Pellacani, Microstructure and mechanical properties of porcelainized stoneware tiles, in: C. Palmonari (Ed.), Fourth Euro Ceramics, Vol. 11, Faenza Editrici S.p.A, Florencia, 1995, pp. 319-326.

25. M.J. Orts, A. Escardino, J.L. Amorós, F. Negre, Microstructural changes during the firing of stoneware floor tiles, Applied Clay Science 8 (1993) 193-205.

26. Leonelli, F. Bondioli, P. Veronesi, M. Romagnoli, T. Manfredini, G.C. Pellacani, V. Cannillo, Enhancing the mechanical properties of porcelain stoneware tiles: a microstructural approach, Journal of the European Ceramic Society 21 (2001) 785-793.

27. A. Escardino, J.L Amoros y J.E. Enrique, Estudio de pastas de gres para pavimentos, Boletín de la Sociedad Española de Cerámica y Vidrio 20 (1) (1981) 17-24.

28. A.W. Norris, D. Taylor, I. Thorpe, Range curves: An experimental method for the study of vitreous pottery bodies, Transactions of the British Ceramic Society 78 (1979) 102-108.

29. W.D. Kingery, Introduction to ceramics. J. Wiley \& Sons, New York, 1976.

30. S. Maity, B.K. Sarkar, Development of high-strength whiteware bodies, Journal of the European Ceramic Society 16 (1996) 1083-1088.

31. Y. Ohya, Y. Takahashi, Acoustic emission from a porcelain body during cooling, Journal of the American Ceramic Society 82 (2) (1999) 445-448.

32. S.T. Ludin, Microstructure of porcelain, Natl. Bur. Stand (U.S.), Misc. Publ., 257 (1964) 93-106. 